\title{
Analisa Perbandingan Kolom Komposit Inside Steel dan Outside Steel Terhadap Kapasitas Tahanan Aksial dan Momen
}

\author{
Jaka Propika ${ }^{1}$, Dita Kamarul Fitriyah ${ }^{2}$, Yanisfa Septiarsilia ${ }^{3}$ \\ 1,2,3 Teknik Sipil, FTSP, Institut Teknologi Adhi Tama Surabaya - Jl. Arif Rahman Hakim No.100 \\ *e-mail corresponding author : jakapropika@gmail.com. - 081252887733
}

\begin{abstract}
ABSTRAK
Penggunaan kolom komposit telah banyak digunakan di berbagai bangunan bangunan tinggi. Dan pada umumnya, Kolom komposit dibagi menjadi 2 macam, yaitu kolom komposit inside steel dan outside steel dengan struktur baja terbungkus oleh beton disebut dengan kolom inside steel atau bisa saja disebut Concrete Encased Column. Sedangkan untuk baja yang berisi beton disebut dengan kolom outside steel atau juga disebut Concrete Filled Column. Penggunaan struktur kolom komposit outside steel sebagai kolom utama dalam mendukung beban lateral pada struktur rangka bangunan belum lazim digunakan dalam perkembangan konstruksi saat ini. Oleh karena itu, perlu dilakukan analisa kekuatan dari 2 macam kolom komposit agar diketahui jenis kolom komposit yang paling efektif dan memiliki kekuatan paling tinggi. Perhitungan yang dilakukan dengan menggunakan perhitungan manual pada kolom komposit inside steel dan outside steel yang berbentuk kotak, sedangkan untuk perhitungan dengan menggunakan program CSICOL dilakukan pada seluruh kolom komposit. Hasil nilai ØPn dan ØMn kemudian dibandingkan antara perhitungan manual dengan program CSICOL. Hasil perhitungan menunjukan bahwa kemampuan kolom komposit outside steel lebih baik dibandingkan kolom komposit inside steel dengan menggunakan standar volume dari ukuran kolom komposit inside steel kotak 400x400 mm. Kolom komposit outside steel berbentuk bundar dengan diameter $431 \mathrm{~mm}$ lebih unggul sebesar $17 \%$ dalam menahan gaya aksial nominal (ØPn) dibandingkan semua tipe kolom komposit yang lain. Sedangkan kolom komposit outside steel berbentuk kotak dengan ukuran 405.70x405.70 mm lebih unggul menahan momen nominal (ØMn) sebesar 10,5 \% dibandingkan semua tipe kolom komposit yang lain.
\end{abstract}

Kata kunci : kolom komposit; inside steel (concrete- encased column); outside steel (concrete-filled column).

\begin{abstract}
The use of composite columns has been widely used in various high-rise buildings. Composite columns are generally divided into two types: composite columns inside steel and outside steel columns with a steel structure wrapped in concrete called an inside steel column (concrete encased column), while steel containing concrete is called an outside steel column (concretefilled column). The use of a composite column structure outside steel as the main column in supporting lateral loads in the building frame structure is not yet commonly used in current construction developments. Therefore, it is necessary to consider the strengths of 2 types of composite columns to know which type of composite column is the most effective and has the highest strength. Calculations are performed using manual calculations on composite columns inside steel and outside steel in the form of a box, while calculations using the CSiCOL program are carried out on all composite columns. The results of the ØPn and ØMn values are then compared between manual calculations and the CSiCOL program. The calculation results show that the composite outside steel column's ability is better than the inside steel composite column by using a standard volume from the size of the composite column inside steel box $400 \times 400 \mathrm{~mm}$. The round composite outside steel column with a $431 \mathrm{~mm}$ diameter is 17\% superior in withstanding nominal axial force (ØРn) than all other composite column types. While the outside steel composite column in the form of a box with a size of $405.70 \times 405.70$ $\mathrm{mm}$ is superior to withstand the little moment (ØМn) by $10.5 \%$ compared to all other types of composite columns.
\end{abstract}

Keywords : composite column; inside steel (concrete-encased column); outside steel (concrete-filled column).

Cara mengutip: Propika, J., Fitriyah, D. K., dan Septiarsilia, Y. (2020). Analisa Perbandingan Kolom

Komposit Inside Steel dan Outside Steel Terhadap Kapasitas Tahanan Aksial dan Momen. Reka Buana : Jurnal

Ilmiah Teknik Sipil dan Teknik Kimia, 5(2), 159-170. http:/ /dx.doi.org/10.33366/rekabuana.v5i2.1947 


\section{PENDAHULUAN}

Kolom komposit adalah kolom yang menggunakan gabungan dua material atau lebih. Pada saat ini penggunaan kolom komposit dengan material beton bertulang (komposit beton dan baja tulangan) telah banyak digunakan di berbagai bangunan tinggi[1]. Selain kolom beton bertulang, terdapat kolom komposit dengan penambahan material baja profil, yang dibagi menjadi dua macam yaitu kolom komposit inside steel dan outside steel dimana bagian kolom dengan struktur baja terbungkus oleh beton dinamakan dengan kolom inside steel (concrete encased column) sedangkan untuk baja yang berisi beton dinamakan kolom outside steel (concrete filled column )[2].

Terdapat dua peraturan yang mengatur tentang kolom komposit di Amerika, yaitu peraturan beton ACI 318 dan peraturan baja AISC LRFD. Kedua peraturan ini mempunyai cara yang berbeda dalam menghitung kekuatan kolom komposit. Perbedaan tersebut dikarenakan dasar yang digunakan adalah berbeda, ACI 318 mengenalkan dasar beton, sedangkan AISC LRFD melihatnya dengan dasar baja. Dari beberapa penelitian yang telah dilakukan perhitungan kapasitas kolom dengan peraturan ACI 318 lebih akurat dibandingkan dengan AISC LRFD dan juga dalam ACI 318 tidak ada perbandingan luas penampang kolom dengan luas baja [3].

Penggunakan struktur kolom komposit outside steel sebagai kolom utama dalam mendukung beban lateral pada struktur rangka bangunan belum lazim dalam perkembangan konstruksi saat ini[4]. Oleh karena itu dilakukan perhitungan terhadap kekuatan masing - masing jenis kolom komposit sehiangga hasil yang diperoleh menunjukkan jenis kolom komposit yang paling efektif dan memiliki kekuatan paling tinggi, sehingga penggunaanya pada konstruksi dapat dinilai sebagai pemilihan yang tepat[5].

\section{METODE PENELITIAN}

Elemen struktur komposit baja dan beton merupakan struktur yang terdiri dari 2 material atau lebih dengan sifat bahan yang berbeda dan membentuk satu kesatuan sehingga menghasilkan sifat gabungan yang lebih baik. Komposit baja dengan beton didasarkan pada pemikiran bahwa beton mempunyai perilaku yang menguntungkan ketika menerima beban tekan dan perilaku yang kurang menguntungkan ketika menerima beban tarik. Sedangkan baja mempunyai kemampuan bahan yang sama baik untuk beban tarik dan tekan tetapi harus diwaspadai terhadap bahaya tekuk ketika menerima beban tekan. Oleh karena itu, struktur komposit dengan kolom komposit mulai banyak digunakan di luar negeri. Berdasarkan SNI 03-1729-2002 Pasal 12, Jenis kolom komposit terdiri dari dua macam[6], yaitu :

1. Kolom komposit terbungkus beton adalah kolom komposit yang terbuat dari profil baja yang diberi selubung beton di sekeliling (kolom baja berselubung beton) Kolom ini dapat dinamakan kolom komposit Inside Steel (Concrete encased column) yang dapat dilihat pada Gambar 1 dan 2.

2. Kolom komposit terisi beton adalah kolom komposit yang terbuat dari penampang baja berongga dan diisi beton didalamnya (kolom baja berisikan beton). Kolom ini dapat dinamakan kolom komposit Outside Steel (Concrete filled column) yang dapat dilihat pada Gambar 3 dan 4. 


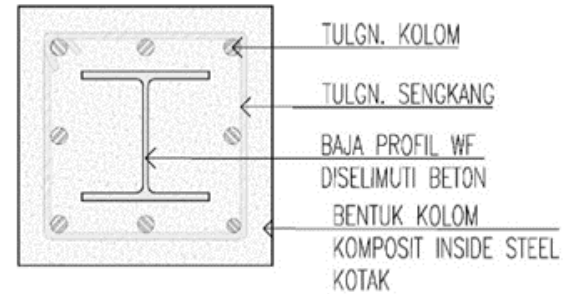

Gambar 1. Kolom Komposit Inside Steel Kotak

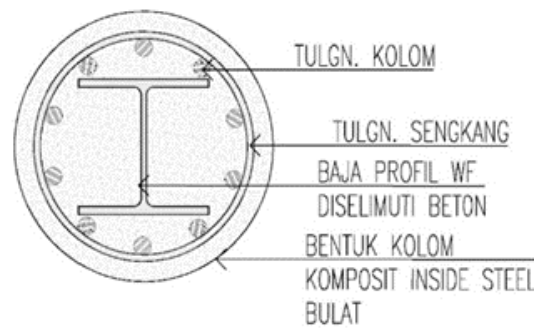

Gambar 2. Kolom Komposit Inside Steel Bundar

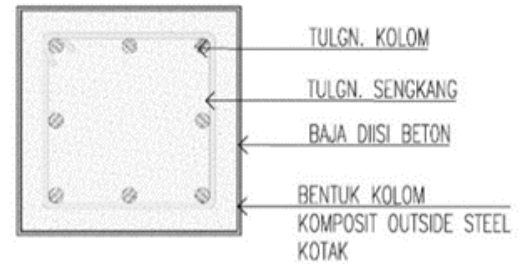

Gambar 3. Kolom Komposit Outside Steel Kotak

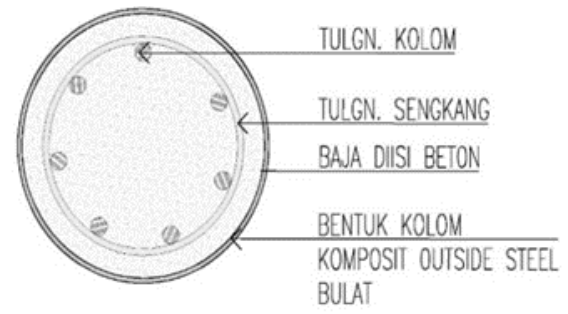

Gambar 4. Kolom Komposit Outside Steel Bundar

Beton dan baja dianggap sebagai satu kesatuan dalam kolom yang dibebani dengan beban aksial.). Kapasitas beban aksial maksimum yang dapat dihitung. Sesuai dengan desain beban aksial maksimum pada komponen struktur nonprategang dengan tulangan pengikat (termasuk kolom bersengkang) [7]: $\varnothing \operatorname{Pn}(\max )=0,80 \varnothing(0,85 \mathrm{fc} \times(\mathrm{Ag}-\mathrm{As})+$ Asx fy

Keterangan :

Ac $=$ Luas beton, inchi ${ }^{2}\left(\mathrm{~mm}^{2}\right)$.

As $=$ Luas penampang baja, inchi ${ }^{2}\left(\mathrm{~mm}^{2}\right)$.

fy $=$ Tegangan leleh minimum yang disyaratkan dari penampang baja, ksi (Mpa).

$\mathrm{fc}=$ Kuat tekan minimum beton, ksi (Mpa).

Momen lentur pada kolom terjadi saat adanya beban aksial yang menekan kolom ditambah dengan bertambahnya eksentrisitas. Semakin besar bertambahnya eksentrisitas pada kolom dapat menyebabkan keruntuhan terjadi akibat tulangan meleleh sebelum hancurnya beton.

Menurut Nawy (1985), momen tahan nominal Mn yaitu sebesar Pne dapat diperoleh dengan menuliskan keseimbangan momen terhadap pusat plastis penampang, Untuk kolom uang penulangannya simetris, pusat plastisnya sama dengan pusat geometrisnya.

$\mathrm{Mn}=$ Pne $=$ Cc. $\mathrm{y}+\sum \mathrm{Fs} .($ ya-yi $)+\sum$ Fr. (ya-yi)

Maka dari persamaan 1 dan 2 menurut Nawy dapat juga ditulis sebagai :

Pn $=0,85$. fc. b. $\alpha b+$ As'. fs' + Asr'. fr'- As. fs + Asr. fr....

$\mathrm{Mn}=$ Pne $=0,85 \cdot f \mathrm{fc} \cdot \mathrm{b} \cdot \alpha \mathrm{b} \cdot(\mathrm{y})+$ As'. fs'. (yayi) + Asr'. fr'.(ya-yi) - As. fs. (ya-yi) + Asr. fr. (ya-yi)

Material beton dalam kolom beton bertulang maupun kolom komposit akan meningkat kekuatannya apabila dilakukan pengekangan yang cukup terhadap kolom tersebut[8]. Berikut rumus perhitungannya[9] :

$\mathrm{fcc}=0,85 \mathrm{fc}+4 \mathrm{frp}$ 
$\operatorname{frp}=\beta 2 t /(D-2 t) f y$.

$\beta=$ ve -us

v'e $=0,2312+0,3582$ v'e $-0,1524(\mathrm{fc} / \mathrm{fy})$

$+4,843$ v'e $(\mathrm{fc} / \mathrm{fy})-9,169$

$(\mathrm{fc} / \mathrm{fy})^{2}$

v'e $=0,881 \times 10^{-6}(\mathrm{D} / \mathrm{t})^{3} 2,58 \times 10^{-4}(\mathrm{D} / \mathrm{t})^{2}+$ $1,953 \times 10^{-2}(\mathrm{D} / \mathrm{t}) 0,4011$

Diagram interaksi kolom dibuat dengan pertolongan dua buah sumbu (yaitu sumbu vertikal dan sumbu horizontal) yang saling berpotongan dan tegak lurus semuanya. Sumbu vertikal menggambarkan besar beban aksial $\mathrm{P}$ atau gaya normal $\mathrm{N}$, sedangkan sumbu horizontal menggambarkan besar momen lentur $\mathrm{M}$ yang dapat ditahan oleh kolom[10].

\section{METODE PENELITIAN}

Adapun metode penelitian yang akan dilakukan, sebagai berikut :

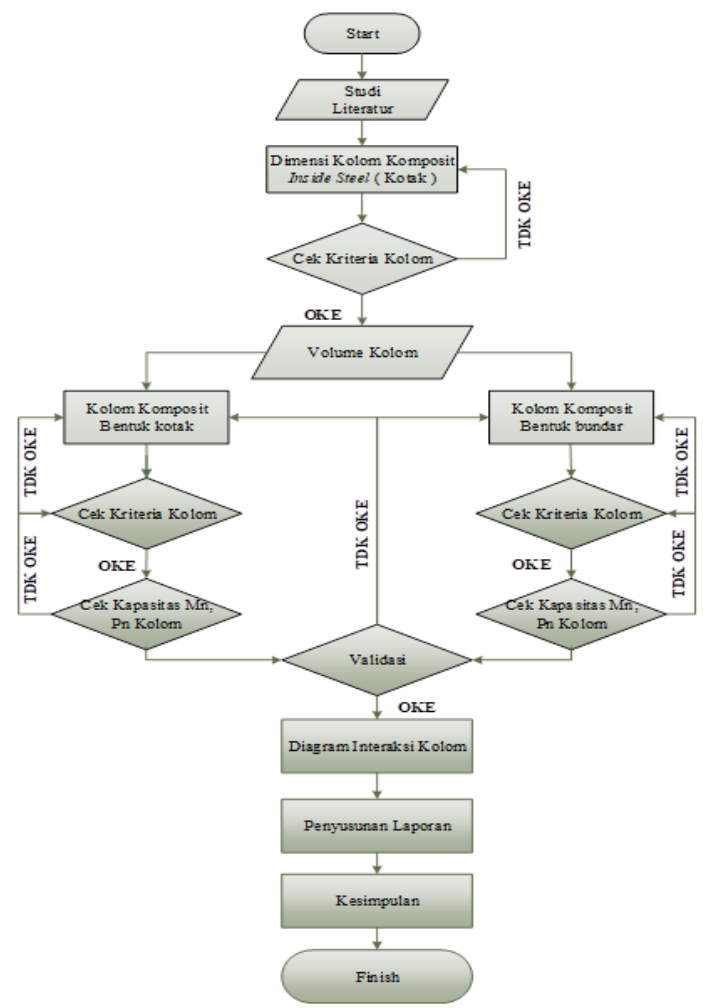

\section{Gambar 5. Diagram Alir Urutan \\ Penelitian}

\subsection{Pengumpulan Data.}

Data - data yang digunakan dalam penelitian ini terdiri dari :

- Mutu Beton Kolom (fc') : $40 \mathrm{Mpa}$

- Mutu Baja Tulangan :

BJTP ( fyr ),: 300 Mpa untuk notasi $\varnothing$.

BJTD ( fyr ): 300 Mpa untuk notasiD.

- Mutu Baja (fy ): 300 Mpa.

Dimensi Kolom Komposit Inside Steel (Kotak) b x h (panjang x lebar ): 400 x 400 ( $\mathrm{mm})$.

- Rasio :

Luas Penampang profil baja minimal sebesar $1 \%$ dari luas penampang komposit total ( As $\geq 1 \%$ Ag).

- Rasio tulangan kolom adalah $1 \%$.

- Syarat jarak sengkang/ pengikat lateral : $2 / 3 \times$ b (atau h $)>250 \mathrm{~mm}$.

- Luas tulangan longitudinal : $1 / 4 \mathrm{x} \pi \mathrm{x}$ $\mathrm{D}^{2}>0,18 \times$ ( jarak antar tulangan $)$.

- Luas tulangan sengkang: $1 / 4 \times \pi \times \mathrm{D}^{2}$ $>0,18 \times 250 \mathrm{~mm}$.

\subsection{Cek Kriteria Kolom Komposit Inside \& Outside Steel.}

Pengecekan tersebut meliputi cek penampang kolom, cek rasio baja dan tulangan, cek tulangan longitudinal serta syarat lainnya. Setelah dilakukan pengecekan, jika dimensi tersebut telah sesuai dengan ketentuan yang berlaku maka dilanjutkan untuk perhitungan kapasitas kolom. 


\subsection{Perhitungan Manual Kapasitas} Aksial Tekan, Tarik, Momen Komposit Inside \& Outside Steel ( Kotak ).

Perhitungan kapasitas kolom komposit yang dibandingkan adalah untuk mencari nilai dari gaya aksial tekan, tarik dan momen yang kemudian dikalikan dengan angka koefisien reduksi untuk mendapatkan nilai gaya aksial (ØPn ) dan momen nominal (ØMn) kolom komposit. Perhitungan kapasitas kolom secara manual hanya dilakukan pada kolom komposit inside steel, outside steel (dengan fcc) dan outsite steel (tanpa fcc) yang berbentuk kotak. Sedangkan kolom komposit inside steel dan outside steel yang berbentuk bundar, perhitungannya dilakukan dengan program.

\subsection{Perhitungan Kapasitas Aksial}

Tekan, Tarik, Momen Komposit Inside \& Outside Steel ( Bundar) dengan Program Finite Element.

Perhitungan kolom komposit inside steel dan outside steel dengan menggunakan bantuan program finite element.

\subsection{Validasi Perhitungan Manual} dengan Program pada Kolom Komposit Inside \& Outside Steel yang dibandingkan.

Hasil yang didapatkan (gaya aksial nominal (ØРn), momen nominal (ØMn), diagram interaksi dari hasil perhitungan manual dan program finite element) selanjutnya dilakukan pengecekan untuk masing - masing nilai, dimana hasil dari perhitungan manual sudah sama/hampir mendekati dengan hasil running program.

Nilai dari gaya aksial nominal (ØPn) dan momen nominal (ØMn) perhitungan tersebut kemudian dicari presentasi tingkat perbedaan dengan perhitungan program
CSICOL. Jika nilai perhitungan dianggap mendekati hasil dari running program maka dapat dilanjutkan ke tahap selanjutnya, jika tidak, maka perlu dilakukan analisa kembali terhadap perhitungan manual ataupun program finite element. Diagram interaksi pada seluruh kolom komposit inside steel dan outside steel yang dibandingkan disuperimpose menjadi satu agar mempermudah dan mengetahui kapasitas kolom komposit yang paling besar dibandingkan dengan yang lain.

\section{HASIL DAN PEMBAHASAN}

Perhitungan kapasitas gaya aksial dan momen kolom komposit dilakukan secara bertahap, mulai dari perhitungan gaya dalam yang terjadi pada beton, hingga didapatkan reaksi gaya, sampai tahap analisis perbandingan pada diagram interaksi kolom komposit.

a) Nilai ØPn dan ØMn Kolom Komposit Inside Steel (Kotak).

Hasil dari perhitungan gaya aksial nominal dan momen nominal pada kolom komposit inside berbentuk kotak dapat dilihat pada Tabel 1, kemudian perbedaan gambar diagram interkasinya dapat dilihat pada Gambar 6.

Tabel 1. Perbandingan Nilai ØPn dan ØMn kolom komposit inside steel (kotak) manual dan program CSICOL

\begin{tabular}{|c|c|c|c|c|c|c|}
\hline \multirow{4}{*}{$\begin{array}{c}\text { Keterang } \\
\text { an }\end{array}$} & \multicolumn{6}{|c|}{ Kolom Komposit Inside Steel (Kotak) } \\
\hline & \multicolumn{2}{|c|}{ Manual } & \multicolumn{2}{|c|}{ Program } & \multirow{2}{*}{\multicolumn{2}{|c|}{$\frac{\text { Presentasi }}{\text { Perbedaan }}$}} \\
\hline & $\mathrm{Pn}$ & $\mathrm{Mn}$ & $\mathrm{Pn}$ & $\mathrm{Mn}$ & & \\
\hline & $\mathrm{kN}$ & $\mathrm{kNm}$ & $\mathrm{kN}$ & $\mathrm{kNm}$ & $\%$ & $\%$ \\
\hline $\begin{array}{l}\text { ØPn } \\
\text { tekan } \\
\text { maksimal }\end{array}$ & 4386 & 0 & 4095 & 0 & 3.4 & 0.0 \\
\hline $\begin{array}{l}\text { ØPn } \\
\text { tekan }\end{array}$ & 4386 & 169 & 4095 & 150 & 3.4 & 3.3 \\
\hline $\begin{array}{l}\text { ØPn ,Mn } \\
\text { balanced }\end{array}$ & 2781 & 279 & 2897 & 261 & 2.1 & 3.3 \\
\hline $\begin{array}{l}\text { ØPn } \\
\text { tarik } \\
\text { maksimal }\end{array}$ & 2498 & 0 & 2497 & 0 & 0.0 & 0.0 \\
\hline
\end{tabular}




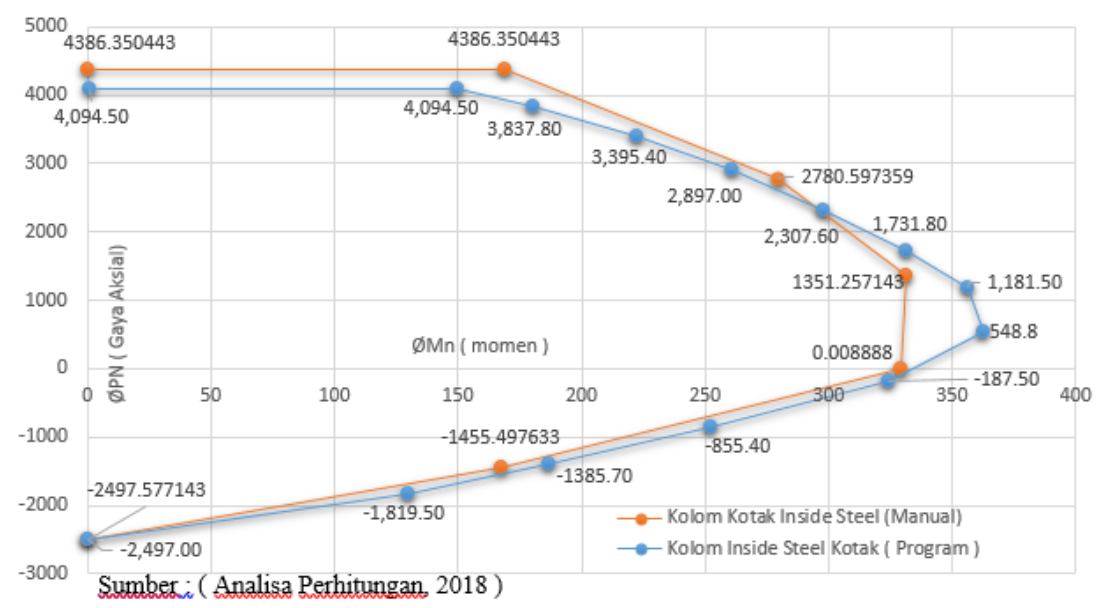

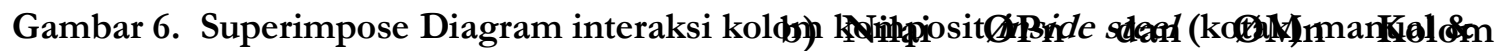
program CSIC 69 mposit Outside Steel (Kotak)

Hasil dari perhitungan gaya aksial

Pada perbandingan kolom komposit inside steel berbentuk kotak pada Tabel 1 dan Gambar 6 terdapat perbedaan nilai dimana pada hasil gaya aksial nominal (ØРn) sebesar 2,2361 \%, nilai momen nominal (ØMn) sebesar 1,6586\%. Hal dikarenakan pemakaia nilai fc (kuat tekan beton) yang digunakan pada perhitungan manual adalah nilai fc awal sedangkan pada program CSiCOL telah memakai fcc yang memperhitungkan kekuatan pengekangan sengkang. nominal dan momen nominal pada kolom komposit inside berbentuk kotak dapat dilihat pada Tabel 2 dan 3, kemudian perbedaan gambar diagram interkasinya dapat dilihat pada Gambar 7.

Pada perbandingan kolom komposit outside steel berbentuk kotak dalam perhitungan manual dengan fc dan program CSiCOL terdapat perbedaan nilai dimana pada hasil gaya aksial nominal (ØPn ) sebesar $11,1741 \%$, nilai momen nominal (ØMn) sebesar 6,7008\% .

Tabel 2. Perbandingan nilai ØPn dan ØMn kolom komposit outside steel (kotak) manual dan program CSICOL fc.

\begin{tabular}{lcccccc}
\hline \multicolumn{1}{c}{ Keterangan } & \multicolumn{3}{c}{ Kolom Komposit Inside Steel (Kotak) } \\
\hline & \multicolumn{2}{c}{ Manual } & \multicolumn{2}{c}{ Program } & \multicolumn{2}{c}{ Presentasi } \\
\hline & $\mathrm{Pn}$ & $\mathrm{Mn}$ & $\mathrm{Pn}$ & $\mathrm{Mn}$ & \multicolumn{2}{c}{ Perbedaan } \\
\hline & $\mathrm{kN}$ & $\mathrm{kNm}$ & $\mathrm{kN}$ & $\mathrm{kNm}$ & $\%$ & $\%$ \\
\hline $\begin{array}{l}\text { ØPn tekan } \\
\text { maksimal }\end{array}$ & 4484 & 0.0 & 4756 & 0.0 & 5.7 & 0.0 \\
\hline ØPn tekan & 4484 & 311 & 4756 & 208 & 5.7 & 20 \\
\hline ØPn ,Mn balanced & 2380 & 498 & 2873 & 443 & 17 & 5.9 \\
\hline $\begin{array}{l}\text { ØPn tarik } \\
\text { maksimal }\end{array}$ & - & 0.0 & - & 0.7 & 16 & 1.0 \\
\hline
\end{tabular}

Sumber : analisa Perhitungan, 2018 
Tabel 3. Perbandingan nilai ØPn dan ØMn kolom komposit outside steel (kotak) manual dan program CSICOL (fcc).

\begin{tabular}{lcccccc}
\hline Keterangan & \multicolumn{3}{c}{ Kolom Komposit Inside Steel (Kotak) } \\
\hline & \multicolumn{2}{c}{ Manual } & \multicolumn{2}{c}{ Program } & \multicolumn{2}{c}{ Presentasi } \\
\hline & $\mathrm{Pn}$ & $\mathrm{Mn}$ & $\mathrm{Pn}$ & $\mathrm{Mn}$ & \multicolumn{2}{c}{ Perbedaan } \\
\hline & $\mathrm{kN}$ & $\mathrm{kNm}$ & $\mathrm{kN}$ & $\mathrm{kNm}$ & $\%$ & $\%$ \\
\hline $\begin{array}{l}\text { ØPn tekan } \\
\text { maksimal }\end{array}$ & 4484 & 0.0 & 4756 & 0.0 & 5.7 & 0.0 \\
\hline ØPn tekan & 4484 & 311 & 4756 & 208 & 5.7 & 20 \\
\hline $\begin{array}{l}\text { ØPn ,Mn } \\
\text { balanced }\end{array}$ & 2380 & 498 & 2873 & 443 & 17 & 5.9 \\
\hline $\begin{array}{l}\text { ØPn tarik } \\
\text { maksimal }\end{array}$ & 3026 & 0.0 & 3605 & 0.7 & 16 & 1.0 \\
\hline
\end{tabular}

Sumber : analisa Perhitungan, 2018

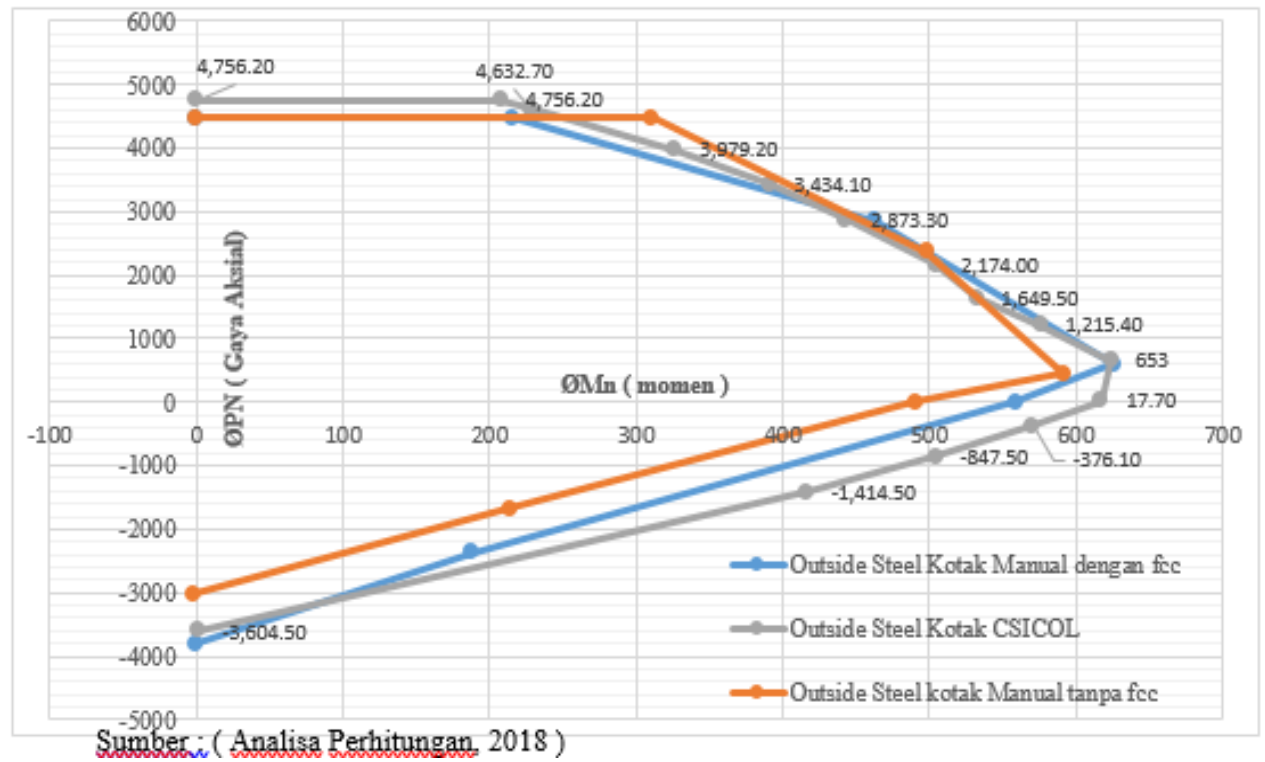

Gambar 7. Superimpose Diagram interaksi kolom komposit outside steel (kotak) manual \& program CSiCOL

Sedangkan pada perhitungan manual dengan fcc dan program CSiCOL terdapat perbedaan nilai dimana pada hasil gaya aksial nominal (ØPn ) sebesar 4,5410\%, nilai momen nominal (ØMn) sebesar 1,2784 $\%$. Perbedaan pada nilai perbandingan kolom komposit outside steel berbentuk kotak dimana perhitungan manualnya menggunakan $\mathrm{fc}$ ataupun fcc serta program CSiCOL menunjukan nilai perbedaan yang disebabkan akibat memperhitungkan kekuatan pengekangan sengkang.

\section{c) Perbandingan Nilai ØPn dan ØMn Kolom Komposit Inside dan Outside Steel (Bundar).}

Hasil perhitungan gaya aksial momen nominal menggunakan program pada kolom komposit inside dan outside steel yang berbentuk bundar untuk mengetahui nilai perbedaannya, dimana nilai yang ditinjau terdiri dari 15 titik yang dapat dilihat pada Tabel 4 dan Gambar 8. 
Tabel 4. Perbandingan nilai ØPn dan ØMn kolom komposit inside dan outside steel bundar pada program CSiCOL

\begin{tabular}{|c|c|c|c|c|c|}
\hline \multicolumn{2}{|c|}{$\begin{array}{l}\text { Kolom Inside } \\
\text { Steel (Bundar) }\end{array}$} & \multicolumn{2}{|c|}{$\begin{array}{c}\text { Kolom } \\
\text { Outside Steel } \\
\text { (Bundar) }\end{array}$} & \multicolumn{2}{|c|}{$\begin{array}{l}\text { Presentasi } \\
\text { Perbedaan }\end{array}$} \\
\hline \multicolumn{4}{|c|}{ Program CSISOL } & & \\
\hline Pn & $\mathrm{Mn}$ & $\mathrm{Pn}$ & $\mathrm{Mn}$ & $\mathrm{Pn}$ & $\mathrm{Mn}$ \\
\hline $\mathrm{kN}$ & $\mathrm{kNm}$ & $\mathrm{kN}$ & $\mathrm{kNm}$ & $\%$ & $\%$ \\
\hline 3827 & 0.0 & 5285 & 0.0 & 27.6 & 0.0 \\
\hline 3827 & 0.5 & 5285 & 157 & 27.6 & 99.7 \\
\hline 3827 & 129 & 5059 & 191 & 24.4 & 32.4 \\
\hline 3790 & 133 & 4482 & 272 & 15.4 & 50.9 \\
\hline 3354 & 176 & 3847 & 345 & 12.8 & 49.1 \\
\hline 2850 & 213 & 3178 & 405 & 10.3 & 47.3 \\
\hline 2233 & 250 & 2289 & 481 & 2.5 & 48.2 \\
\hline 1554 & 284 & 1501 & 524 & 3.3 & 45.8 \\
\hline 876 & 306 & 815 & 556 & 6.9 & 45.0 \\
\hline 115 & 295 & 52.3 & 569 & 54.4 & 48.1 \\
\hline 845 & 225 & 993 & 519 & 14.9 & 56.7 \\
\hline 1510 & 152 & 1522 & 455 & 0.8 & 66.5 \\
\hline 1969 & 93 & 2156 & 369 & 8.7 & 74.8 \\
\hline 2204 & 54.6 & 2706 & 281 & 18.6 & 80.6 \\
\hline 2497 & 0 & 4171 & 0 & 40.1 & 0 \\
\hline \multirow{2}{*}{\multicolumn{6}{|c|}{ Nilai perbedaan ØPn (Gaya Aksial)17.9 }} \\
\hline & & & & & 49.7 \\
\hline
\end{tabular}

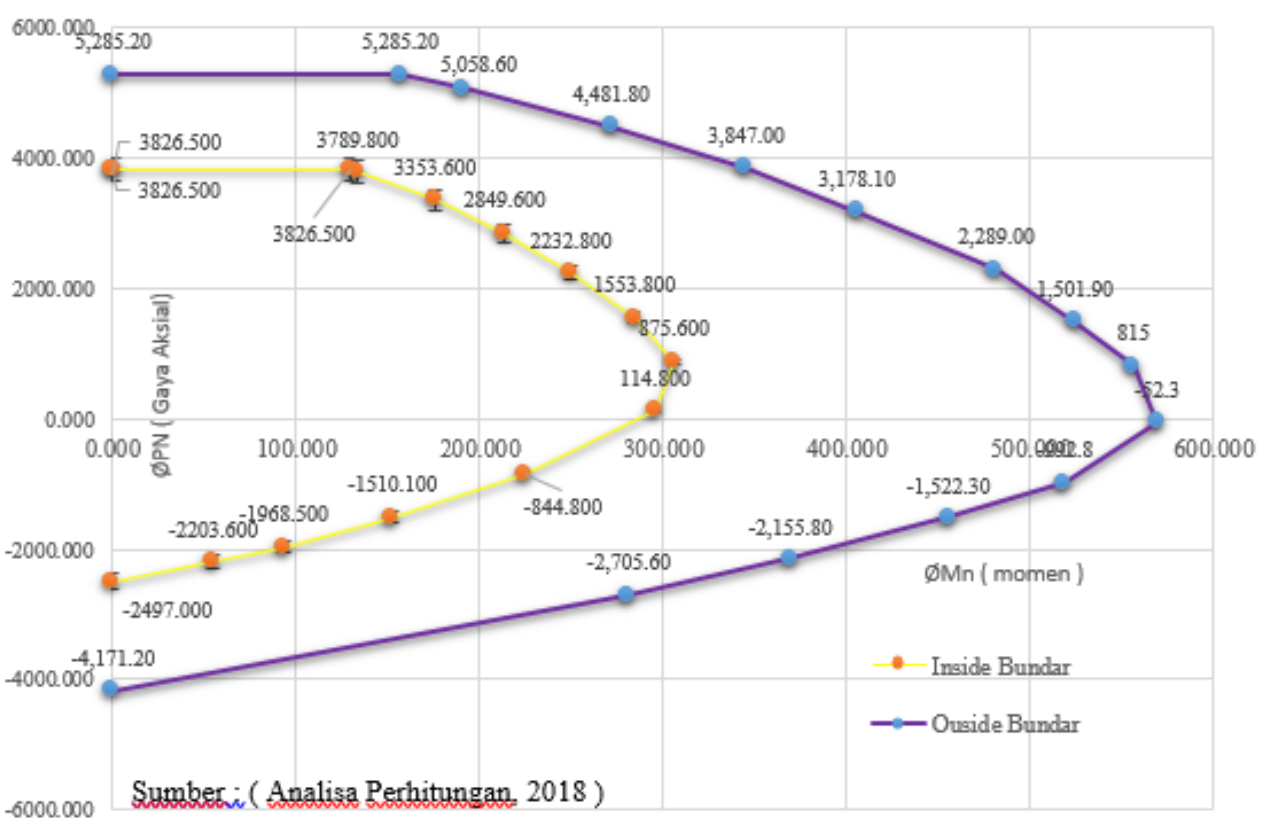

Gambar 8. Superimpose Diagram interaksi kolom komposit inside steel (bundar) dan outside steel (bundar) CSiCOL 
Tabel 5. Perbandingan nilai ØPn seluruh kolom komposit inside dan outside steel kotak.

\begin{tabular}{cccccc}
\hline Keterangan & \multicolumn{3}{c}{ Gaya Aksial Nominal ( ØPn ) Kolom Komposit } \\
\hline & Inside Steel Kotak & \multicolumn{4}{c}{ Outside Steel Kotak } \\
\hline & Manual & CSiCOL & $\begin{array}{c}\text { Manual } \\
\text { fc }\end{array}$ & $\begin{array}{c}\text { Manual } \\
\text { fcc }\end{array}$ & CSiCOL \\
\hline & $\mathrm{Pn}$ & $\mathrm{Pn}$ & $\mathrm{Pn}$ & $\mathrm{Pn}$ & $\mathrm{Pn}$ \\
\hline \multicolumn{7}{c}{$\mathrm{kN}$} & $\mathrm{kN}$ & $\mathrm{kN}$ & $\mathrm{kN}$ & $\mathrm{kN}$ \\
\hline $\begin{array}{c}\text { ØPn tekan } \\
\text { maksimal }\end{array}$ & 4386.4 & 4094.5 & 4483.6 & 4473.3 & 4756.2 \\
\hline ØPn tekan & 4386.4 & 4094.5 & 4483.6 & 4473.3 & 4756.2 \\
\hline $\begin{array}{c}\text { ØPn ,Mn } \\
\text { balanced }\end{array}$ & 2780.6 & 2897.0 & 2379.5 & 2850.8 & 2873.3 \\
\hline $\begin{array}{c}\text { ØPn tarik } \\
\text { maksimal }\end{array}$ & 2497.6 & 2497.0 & 3026.0 & 3802.2 & 3604.5 \\
\hline
\end{tabular}

Sumber : Analisa Perhitungan, 2018

Pada perbandingan kolom komposit inside dan outside steel berbentuk bundar dalam perhitungan program CSiCOL terdapat perbedaan besarnya hasil gaya aksial nominal (ØPn ) sebesar 17,8937\%, nilai momen nominal (ØMn) sebesar 49,6801\% dan $\mathrm{Hal}$ ini menunjukan jika kekuatan dari kolom komposit outside steel bundar lebih besar dibandingkan kolom komposit inside steel bundar.

Seluruh perhitungan kapasitas gaya aksial nominal (ØРn ) dan momen nominal (ØMn) yang telah dikerjakan baik secara manual ataupun program kemudian dianalisa perbedaannya yang dapat dilihat pada Tabel 5, 6, 7 dan 8 .

\section{d) Perbandingan Seluruh Kolom Komposit Inside dan Outside Steel.}

Pada Tabel 5 dan Tabel 6 menunjukan bahwa nilai gaya aksial nominal (ØРn) yang dimiliki Kolom Komposit Outside Steel berbentuk bundar (warna kuning) yang paling besar diantara yang lain, dengan rata - rata perbedaan $17.1 \%$ dibandingkan kolom komposit yang lain.

Tabel 6. Perbandingan nilai ØPn seluruh kolom komposit inside dan outside steel bundar.

\begin{tabular}{ccc} 
Ket & \multicolumn{2}{c}{ Gaya Aksial Nominal ( ØPn ) Kolom Komposit } \\
\hline & Inside Steel Bundar & Outside Steel Bundar \\
\hline & CSiCOL & CSiCOL \\
\hline Pn & Pn \\
\hline $\begin{array}{c}\text { ØPn tekan } \\
\text { maksimal }\end{array}$ & 3826.5 & 5285.2 \\
\hline ØPn tekan & 3826.5 & 5285.2 \\
\hline $\begin{array}{c}\text { ØPn ,Mn } \\
\text { balanced }\end{array}$ & 2232.8 & 2289.0 \\
\hline $\begin{array}{c}\text { ØPn tarik } \\
\text { maksimal }\end{array}$ & 2497.0 & 4171.2 \\
\hline
\end{tabular}

Sumber : analisa Perhitungan, 2018 
Tabel 7. Perbandingan nilai ØMn seluruh kolom komposit inside dan outside steel kotak.

\begin{tabular}{|c|c|c|c|c|c|}
\hline \multirow[t]{3}{*}{ Ket } & \multicolumn{4}{|c|}{$\begin{array}{c}\text { Gaya Aksial Nominal ( ØPn ) Kolom } \\
\text { Komposit }\end{array}$} & \multirow[b]{3}{*}{ CSiCOL } \\
\hline & \multicolumn{2}{|c|}{ Inside Steel Kotak } & \multicolumn{2}{|c|}{ Outside Steel Kotak } & \\
\hline & Manual & CSiCOL & $\begin{array}{l}\text { Manual } \\
\text { fc }\end{array}$ & $\begin{array}{l}\text { Manual } \\
\text { fcc }\end{array}$ & \\
\hline & $\mathrm{Mn}$ & $\mathrm{Mn}$ & $\mathrm{Mn}$ & $\mathrm{Mn}$ & $\mathrm{Mn}$ \\
\hline & kN.m & kN.m & kN.m & kN.m & kN.m \\
\hline $\begin{array}{l}\text { ØPn tekan } \\
\text { maksimal }\end{array}$ & 0.0 & 0.0 & 0.0 & 0.0 & 0.0 \\
\hline ØPn tekan & 168.7 & 149.5 & 310.9 & 215.5 & 207.6 \\
\hline $\begin{array}{l}\varnothing \mathrm{Pn}, \mathrm{Mn} \\
\text { balanced }\end{array}$ & 279.2 & 261.1 & 498.4 & 463.4 & 443.0 \\
\hline $\begin{array}{l}\text { ØPn tarik } \\
\text { maksimal }\end{array}$ & 0.0 & 0.0 & 0.0 & 0.0 & 0.7 \\
\hline
\end{tabular}

Tabel 8. Perbandingan nilai ØMn seluruh kolom komposit inside dan outside steel bundar.

\begin{tabular}{ccc}
\hline Ket & \multicolumn{2}{c}{ Gaya Aksial Nominal ( ØPn ) Kolom Komposit } \\
\hline & Inside Steel Bundar & Outside Steel Bundar \\
\hline & CSiCOL & CSiCOL \\
\hline Mn & Mn \\
\hline $\begin{array}{c}\text { OPn tekan } \\
\text { maksimal }\end{array}$ & 0.0 & $\mathrm{kN} . \mathrm{m}$ \\
\hline ØPn tekan & 129.0 & 0.0 \\
\hline $\begin{array}{c}\text { ØPn ,Mn } \\
\text { balanced }\end{array}$ & 249.5 & 156.5 \\
\hline $\begin{array}{c}\text { ØPn tarik } \\
\text { maksimal }\end{array}$ & 0.0 & 481.3 \\
\hline Sumber: Analima Perhitungan, 2018
\end{tabular}

Sumber : Analisa Perhitungan, 2018

Tabel 9. Perbandingan nilai ØPn dan ØMn pada kolom komposit outside steel kotak dan bundar.

\begin{tabular}{ccccccc}
\hline $\begin{array}{c}\text { Kolom Outside Steel } \\
\text { Kotak }\end{array}$ & \multicolumn{2}{c}{$\begin{array}{c}\text { Kolom } \\
\text { Outside Steel } \\
\text { Bundar }\end{array}$} & \multicolumn{2}{c}{$\begin{array}{c}\text { Presentasi } \\
\text { Perbedaan }\end{array}$} \\
\hline \multicolumn{2}{c}{ Program } & \multicolumn{2}{c}{ Program } & & \\
\hline $\mathrm{Pn}$ & $\mathrm{Mn}$ & $\mathrm{Pn}$ & $\mathrm{Mn}$ & $\mathrm{Pn}$ & $\mathrm{Mn}$ \\
\hline $\mathrm{kN}$ & $\mathrm{kNm}$ & $\mathrm{kN}$ & $\mathrm{kNm}$ & $\%$ & $\%$ \\
\hline 4756.2 & 0.0 & 5285.2 & 0.0 & 10.0 & 0.0 \\
\hline 4756.2 & 207.6 & 5285.2 & 156.5 & 10.0 & 24.6 \\
\hline 4632.7 & 227.5 & 5058.6 & 190.8 & 8.4 & 16.1 \\
\hline 3979.2 & 326.6 & 4481.8 & 271.5 & 11.2 & 16.9 \\
\hline 3434.1 & 390.6 & 3847.0 & 345.1 & 10.7 & 11.6 \\
\hline 2873.3 & 443.0 & 3178.1 & 405.3 & 9.6 & 8.5 \\
\hline 2174.0 & 504.6 & 2289.0 & 481.3 & 5.0 & 4.6 \\
\hline 1649.5 & 531.9 & 1501.9 & 524.2 & 8.9 & 1.4 \\
\hline 1215.4 & 575.8 & 815.0 & 556.0 & 32.9 & 3.4 \\
\hline
\end{tabular}




\begin{tabular}{cccccc}
\hline 653.0 & 623.7 & 52.3 & 569.0 & 92.0 & 8.8 \\
\hline 17.7 & 617.3 & 992.8 & 518.7 & 98.2 & 16.0 \\
\hline 376.1 & 570.2 & 1522.3 & 455.2 & 75.3 & 20.2 \\
\hline 847.5 & 504.1 & 2155.8 & 369.1 & 60.7 & 26.8 \\
\hline 1414.5 & 416.3 & 2705.6 & 281.0 & 47.7 & 32.5 \\
\hline 3604.5 & 0.7 & 4171.2 & 0.0 & 13.6 & 0.0 \\
\hline \multicolumn{7}{c}{ Nilai Perbedaan ØPn } & 33.0 \\
\hline \multicolumn{7}{c}{ Nilai Perbedaan ØMn } & & 12.8 \\
\hline
\end{tabular}

Sumber : analisa Perhitungan, 2018

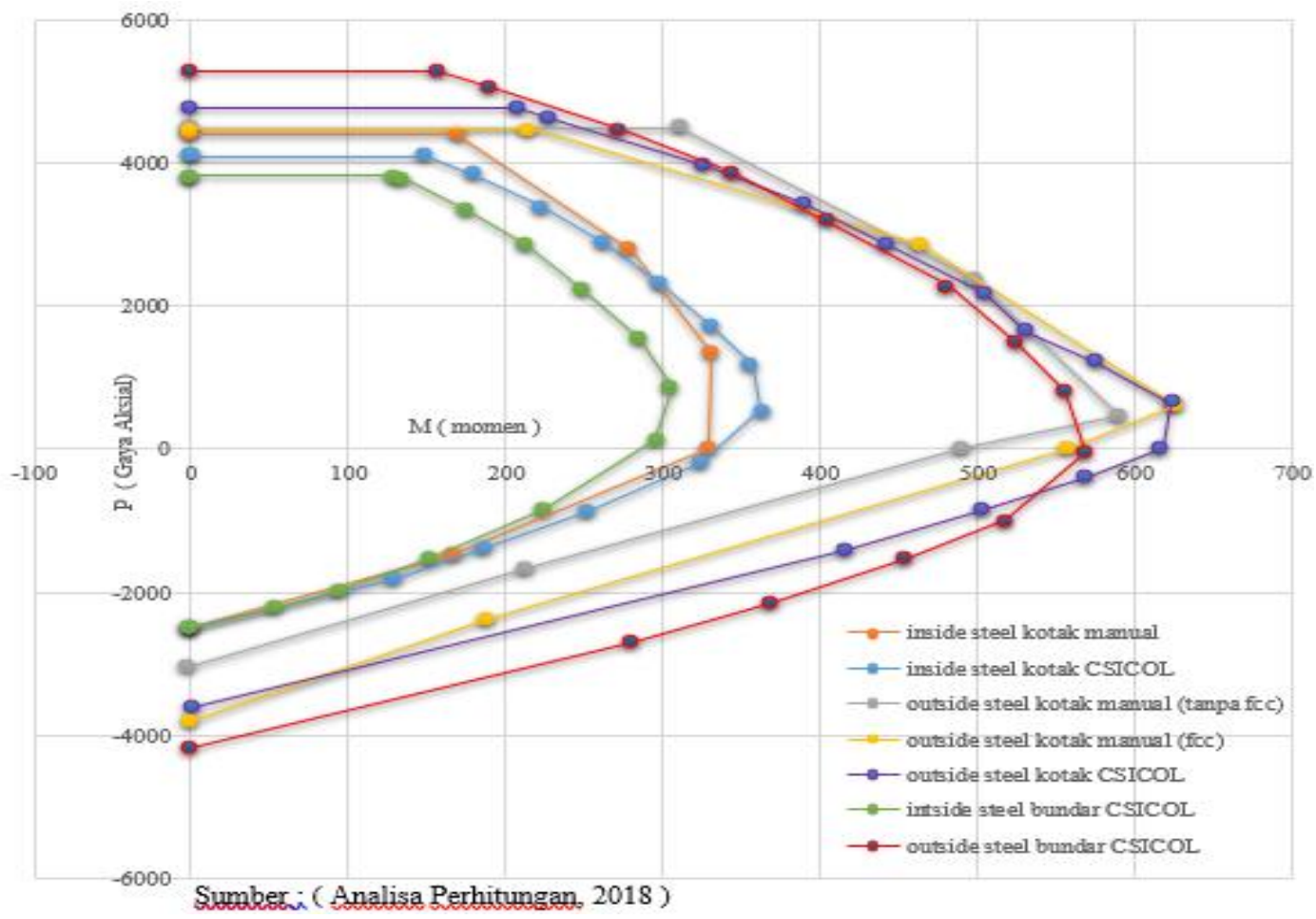

Gambar 8. Superimpose diagram interaksi seluruh kolom komposit inside dan outside steel yang dibandingkan.

Pada Tabel 7 dan Tabel 8 menunjukan bahwa nilai momen nominal (ØMn) yang dimiliki Kolom Komposit Outside Steel berbentuk kotak (warna hijau) yang paling besar diantara yang lain dengan presentasi perbedaan rata - rata lebih besar $10.5 \%$ dibandingkan kolom komposit yang lain. Dari Tabel 5-9 dan Gambar 9 didapatkan bawah kolom komposit outside steel lebih kuat dibandingkan kolom komposit inside steel karena memiliki nilai gaya aksial nominal (ØРn) dan momen nominal (ØMn) lebih besar. Dari Tabel 7 menunjukan bahwa kolom komposit outside steel yang berbentuk bundar lebih unggul dengan presantase 33\% dalam gaya aksial nominal (ØРn) sedangkan kolom komposit outside steel yang berbentuk kotak lebih unggul pada momen nominal (ØMn) sebesar 12,8 $\%$.outside steel berbentuk kotak lebih besar $12,8 \%$ dari kolom komposit outside steel berbentuk kotak dan bundar. 


\section{KESIMPULAN}

Dari nilai gaya aksial nominal ( ØPn ) dan momen nominal ( $\varnothing \mathrm{Mn}$ ) dengan standart ukuran volume kolom komposit inside steel kotak 400x400 (mm), menunjukan bahwa kolom komposit type outside steel lebih unggul dibandingkan dengan kolom komposit inside steel. Dimana kolom komposit outside steel yang berbentuk bundar dengan diameter $431 \mathrm{~mm}$, lebih unggul sebesar $17 \%$ dalam menahan gaya aksial nominal (ØРn) dibandingkan semua type kolom komposit yang lain. Sedangkan kolom komposit outside steel berbentuk kotak dengan ukuran $405.70 \times 405.70$ (mm), lebih unggul menahan momen nominal (ØMn) sebesar 10,5\% dibandingkan semua type kolom komposit yang lain.

\section{DAFTAR PUSTAKA}

[1] K. Baja and K. K. Baja-beton, "Alfin Rico Simanjuntak 1 dan Johannes Tarigan 2 1," no. 1.

[2] A. H. A. Al-razaq, "Analysis of Reinforced Concrete Columns Fitted Inside Steel Casings," Kufa J. Eng., vol. 6, no. 1, 2015.

[3] C. C. Weng and S. I. Yen, "Comparisons of concrete-encased composite column strength provisions of ACI code and AISC specification," Eng. Struct., vol. 24, no. 1, pp. 59-72, 2002, doi: 10.1016/S0141-0296(01)00067-0.

[4] T. Ishizawa and M. Iura, "Analysis of partially concrete-filled steel tubular columns subjected to cyclic loadings," C. - Comput. Model. Eng. Sci., vol. 11, no. 3, pp. 121-130, 2006, doi: 10.3970/cmes.2006.011.121.

[5] Y. Arfiadi, "Diagram Interaksi

Perancangan Kolom Dengan

Tulangan Pada Empat Sisi

Berdasarkan Sni 2847:2013 Dan Aci

318M-11," J. Tek. Sipil, vol. 13, no. 4, p. 268, 2017, doi:

10.24002/jts.v13i4.935.

[6] Departemen Pekerjaan Umum, "Tata Cara Perencanaan Struktur Baja untuk Bangunan Gedung," Standar Nas. Indones., 2002.

[7] 2847:2013 SNI, "Persyaratan Beton Struktural untuk Bangunan Gedung," Bandung Badan Stand. Indones., pp. 1-265, 2013.

[8] D. T. Sipil, U. S. Utara, S. Pengajar, and D. Teknik, "Analisis Kekuatan Lentur Dan Daktilitas Pada Penampang Kolom Beton Bertulang, Kolom Baja Dan Kolom Composite Dengan Software 'Xtract' Rudy Tiara 1 , Sanci Barus 2," no. 1. .

[9] K. A. S. Susantha, H. Ge, and T. Usami, "Uniaxial stress-strain relationship of concrete confined by various shaped steel tubes," Eng. Struct., vol. 23, no. 10, pp. 13311347, 2001, doi: 10.1016/S01410296(01)00020-7.

[10] B. Tulangan and B. Gedung, "Baja tulangan Pada konstruksi jenis Ulir Dalam sPesiflkasi," Budhi dharma, pp. 40-48. 